\title{
Olu Ojo
}

Department of Business Administration, Faculty of Management Sciences, Osun State University, Osun State, Nigeria

oluojo@gmail.com,olu.ojo@uniosun.edu.ng

\section{Samuel Adebayo Idowu}

Department of Human Resource Management, Faculty of Social and

Management Sciences, Elizade University, Ondo State, Nigeria

idowusamueladebayo@gmail.com

\section{Haorayau Bolaji Babalola}

Department of Business Administration, Faculty of Management Sciences, Osun State University, Osun State, Nigeria

mobolajiige07@yahoo.com

\section{ORGANIZATIONAL CONFLICT: A CONTEXTUAL EXPLORATION}

Received: September 12, 2020

Accepted: November 16, 2020

https://doi.org/10.46458/27121097.2020.26.131

\section{Review}

\begin{abstract}
This paper examines the concept, causes, classes, consequences and control of organizational conflict. The study discovered that like many other areas of academic endeavor, conflict generates considerable ambivalence and leaves many managers and scholars quite uncertain about its meaning, sources or causes, typologies, effects and remedy. Thus, this study covers the definition of conflict, causes of conflicts in an organizational setting and classifications of organizational conflicts. Other issues discussed are positive and negative consequences of organizational conflicts and steps that are needed to be taken in order to manage, minimize and solve organizational conflicts. This will help in extending the frontier of knowledge in this area of academic discipline.
\end{abstract}

Keywords: Concept of conflict causes of conflict, classifications of conflict, consequences of conflict, control of conflict;

JEL: D74, J52 


\section{INTRODUCTION}

Conflicts are an everyday phenomenon in individual life, group life, corporate life and in the life of each country. When two or more social entities (i.e., individuals, groups, organizations, and nations) come in contact with one another in attaining their objectives, their relationship may become incompatible or inconsistent. Conflicts are inevitable among humans (Rahim 2002). There is growing recognition of the importance of conflict in an organization. A recent survey indicated that managers spend a considerable portion of their time dealing with conflict and that conflict management becomes increasingly important to their effectiveness (Ojo \& Abolade, 2014). Obisi (1996) argues that despite this fact peace forms one of the fundamental factors for enhanced productivity with resultant benefits to both the labour and management as well as for the economic development of the country. It will not be out of place therefore, to consider conflict as an inevitable and desirable factor in the work place. The need for an effective conflict management to ameliorate the problems emanating from conflict and assist organization in their struggle for the attainment of corporate objective cannot be over emphasized. The general objective of this paper is to examine conflict in its entirety. The specific objectives are to: (i) give appropriate definition to the word conflict; (ii) identify the causes of conflicts in an organizational setting; (iii) examine the different classifications or types of conflict that exists; (iv) investigate the consequences of conflict on individuals and organizational performance; and (v) ascertain the methods employed by the organization in solving conflict. This will be added to the existing body of knowledge in this area.

\section{THE CONCEPT OF CONFLICT}

An important task of management is to create an environment in which individuals and groups of people can co-operate with each other to achieve their goals and that of organization. Yet, one persistent problem in organizations is that individuals and work groups compete for limited resources, power, status, etc. to the extent that their competition leads to disruption (or even enhancement) of cooperative endeavors (Chinedu, Vincent \& Enaini, 2018). These competitions (bad or good) are generally known as conflicts. The term "conflict" is so ubiquitous that it is itself in conflict. Hardly, any two authors agree on what the term "conflict" is. This is more difficult since some (although relatively few) authors see organizational conflict to be healthy and useful to the organizations, others see it as having negative impacts on the organizations. Conflict could be viewed as a situation of competition in which the parties are aware of the incomparability of potential future position in which each party wishes to occupy a position that is incompatible with the wishes of the other (Ojo \& Abolade, 2014). In other words, conflict is 
based on the incompatibility of goals and arises from opposing behaviours. It can be viewed at the individual, group or organizational or country level. Azamosa (2014) summarizes conflict as involving total range of behaviours and attitudes that are in contrast between owners/managers on the one hand and working class people on the other. It is a state of disagreement over issues of substance or emotional antagonism and may arise due to anger, mistrust or personality clashes. Schramm-Nielsen (2002) defines a conflict as a state of serious disagreement and argument about something perceived to be important by at least one of the parties involved. According to Fajana (2000), conflict can be defined as a disagreement between two or more parties who perceive that they have incompatible concerns. It exists whenever an action by one party is perceived as preventing or interfering with the goals, needs or actions of another party. Conflict can be regarded as a reality of management and organizational behaviour and can be related to power and politics. Mullins (2005) sees conflict as behaviour intended to obstruct the achievement of some other person's goals. Economic in Business and Economics -127

Conflict is described as the presence of discord that occurs when goals, interests or values of different individuals or groups are incompatible and frustrate each other's attempt to achieve objectives in an organization (Kazimoto, 2013). It is a communication process and an inevitable consequence of transactional relationship manifesting in disagreement and dissonance with and between individuals and groups in the work-environment. In this context, workplace conflict is a fact of life in any organisation as long as people will compete for jobs, power, recognition and security (Adomie \& Anie, 2005). Therefore, the task of management is not to suppress or resolve all conflicts, but to manage them in order to enhance and not to detract from organizational performance. Baron (1990) concludes that conflict is characterized with the following elements:

- Conflict includes opposing interests between individuals or groups in a zero-sum situation,

- Such opposed interests must be recognized for conflict to exist,

- Conflict involves beliefs, by each side, that the other will thwart (or has already thwarted) its interests; that is actions by one or both sides do, in fact, produce thwarting of others' goals (Tochukwu \& Ikenna, 2018); and

- Conflict is a process; it develops out of existing relationships between individuals or groups and reflects their past interactions and the contexts in which these took place and 


\section{CAUSES OF CONFLICT}

In order for conflict to occur, certain conditions must exist. It is thus imperative to understand the underlying conditions that can course conflict. In the words of Fajana (2000), conflicts can arise over a multiple of organizational experiences, such as incompatible goals, differences of values and philosophies or disputes over shared resources. Conflict is perception, so it begins when someone believes that another might obstruct his or her efforts. Conflict could arise because of the employer's quest to maximize profit while the workers representatives are out to ensure continuous improved condition of living for their members. Conflict could also arise as a result of failure to honour agreed items on collective bargaining. Damachi (1999) emphasizes that if those workers rights and employee prerogative are trampled upon, could also cause conflict. These include pay, condition of service, and fringe benefits among others. It is a state of disagreement over issues of substance or emotional antagonism and may arise due to anger, mistrust or personality clashes. In all, every party to industrial action is affected. Armstrong (1990) sees changes as another cause of conflict. Changes according to him are always with us but it is not always welcome. Resistance to change is natural and it arises because of habit once established, few of the unknown, conformity to customary expected ways of behaviour, misunderstanding of implications of change and individual differences. Unless, it is well managed, he said, it could lead to conflict or even crises.

Empirical research findings have provided insights into causative factors of workplace conflict. Hotepo, Asokere, Abdul-Azeez and Ajemunigbohun (2010) found lack of resources, different expectation, competition, lack of cooperation, interdependence and communication problems as factors that have caused conflicts in the Nigerian service industry. In the banking sector in Nigeria, Obasan (2011) identified unacceptable terms of employment, poor human relations between management and workers, non-consultation with employees before making key decisions affecting them, anti-union posture of management and lack of effective mechanism for prevention of conflict as multiple causal factors of workplace conflict.

Authority relationship is another major cause of conflict in organization. In many organizations, there is an underlying tension between managers and employees because most people do not like being told what they have to do. In many organizations, managers have privileges (flexible hours, free personal long-distance calls, and longer breaks). It is observed that very strict managers often have conflicts with their employees. Sometimes people try to engage in conflict to increase their power or status in an organization. 
Office romances can be a cause of workplace conflict. 96 percent of human resource professionals and 80 percent of executives said workplace romances are dangerous because they can lead to conflict within the organization (Lynem, 2003). In the same vein, public displays of affection can make co-workers uncomfortable and accusations of favoritism may occur, especially if it is a supervisor-subordinate relationship. If the relationship goes awry, one party may seek to exact revenge on the other.

Furthermore, jurisdictional ambiguity can cause conflict in the organization. When the lines of responsibility in an organization are uncertain, then jurisdictional ambiguities appear. Employees have a tendency to pass unwanted responsibilities to another person when responsibilities are not clearly stated. Ambiguous goals, jurisdictions, or performance criteria can lead to conflict. Under such ambiguity, the formal and informal rules that govern interaction break down. Ambiguous jurisdictions are often revealed when new programmes are introduced. This is a common occurrence in universities. Ambiguous performance criteria are a frequent cause of conflict between superiors and subordinates (Omisore \& Abiodun, 2014).

\section{CLASSIFICATIONS OF ORGANISATIONAL CONFLICT}

There are many levels or classes of conflicts (Pondy 1967) such as:

- Latent Conflict: Antecedent conditions of conflictual behavior (scarcity of resources, different opinions, etc). Thus, Hunger, 1976, defines conflict as “......an opponent centered episode as series of episodes based upon incompatibility of goals, aims, or values. It involves direct and personal interaction in which the one party is perceived as controlling the desired goal".

- Perceived Conflict: The way people feel or perceive conflictual situation (i. e. hostile, anxious, or whatever). For example, Thomas 1976, sees conflict as "... the process which begins when one party perceives that the other has frustrated or is about to frustrate, some concern of his.

- Felt Conflict: The way people feel when there are conflict tones, hostile, anxious, etc.).

- Manifest Conflict: The way people behave in a conflict situation verbally attacking another's position, withholding information from another group, or physically fighting it out. Thus, Thompson 1960, sees conflict as “... that behavior of organizations members which is expended in opposition to other members".

- Role Conflict: It frequently occurs in the area of superior-subordinate relationship, particular at the first line-middle supervisor's level. The first-line foreman has often been called a "man-in-the-middle" because his superior 
and his superior's superior expect him to represent management to the workers. He is their interface with the employees. At same time his subordinate expect him to represent them to management; and unless he can depend their interests he is likely to lose their sympathetic support, without which he may have great difficulty in running an effective department. Thus, he finds himself in a role conflict situation (de Wit, Jehn \& Scheepers, 2013).

- Relationship Conflict: This type of conflict may arise from the interpersonal tension that exists between the employees of the concerned organization. These conflicts are concerned intrinsically with the persons. They do not concern the project or the assignment at hand.

\section{CONSEQUENCES OF CONFLICT}

According to Ojo and Abolade (2014) consequences of conflict can be classified into two major groups: Functional Conflict and Dysfunctional Conflict. The distinction between functional conflict and dysfunctional conflict rest on whether the organizations interests are served or not. According to Robbins (2005) some types of conflict support the goals of the organization and improve performance; these are functional, constructive forms of conflict, they benefit the organization whereas some forms of conflict do not benefit the organization.

Functional Conflict: This is commonly referred to in management circle as constructive or corporative conflict (Amason, 1986). The functional effects or consequences of conflict are the following:

- Share and Respect Opinions: As members of organization work together in order to solve a particular conflict, they are more willing to exchange and share their opinions with other members of the group. In addition, conflict can also cause members to actively listen to each other as they work and cooperate with each other in order to accomplish the organizational goals.

- Conflict Satisfies Certain Psychological Needs: A number of psychological needs of some members of the organization like dominance, aggression, esteem and ego are met, thereby provides an opportunity for constructive use and release of aggressive urges.

- Facilitates an Understanding of the Problems: Conflict helps organizational members in facilitating an understanding of the problems people have with one another and leads to better coordination among individuals and departments. In addition, this strengthens intra-group relationship.

- Conflict serves as a Motivator: Conflict can motivate an individual to do better and work harder. One's talents and abilities do come to the forefront in a conflict situation. 
- Inspire Creativity: In some organizations conflict is viewed as an opportunity for finding creative solutions to besetting problems. Conflict can inspire members to brainstorm, while examining problems from various perspectives.

- Improves Future Communication: Conflict can bring group members together and help them learn more about each other. From learning more about each other's opinion on topics relevant to the organization's growth and development to understanding each member's preferred communication styles, conflict within an organization can give members the tools necessary to easily solve conflicts in the future (http://Ezine Articles.com).

- Provides Creative and Innovative Ideas: At times, organizational conflicts do result to generation of creative and innovative ideas in the process of finding solution to the problem. For example, employee benefits of the present day are an outcome of the union-management conflict over the past decades.

Dysfunctional or Destructive Conflicts: These are the types of conflict that hinders organizational performance. The dysfunctional effects are:

- Stress: Interpersonal conflict among people at work has been shown to be one of the most frequently noted stressors for employees (Keenan \& Newton, 1985) Conflict has been noted to be an indicator of the broader concept of workplace harassment. It relates to other stressors that might co-occur, such as role conflict, role ambiguity, and workload. It also relates to strains such as anxiety, depression, physical symptoms, and low levels of job satisfaction (Bowling \& Beehr, 2006).

- Decrease in Productivity: When an organization spends much of its time dealing with conflict, members take time away from focusing on the core goals they are tasked with achieving. Conflict causes members to focus less on the project at hand and more on gossiping about conflict or venting about frustrations. As a result, organizations can lose money, donors and access to essential resources (Liu, Spector \& Shi, 2007).

- Distract Primary Purposes: Conflict can distract individuals and groups from their primary purposes, leaving them with less time and resources for other activities. When a conflict involves the use of "heavy contentious tactics," it can cause the individuals or groups involved in the conflict as well as individuals or groups not involved in the conflict to divert time and resources away from other needs.

- In a conflict situation, people may promote their self-interests or personal gains at the cost of others or the organization.

- Conflict may lead to work sabotage, employee morale problems, decline in the market share of product/service and consequent loss of productivity 
Schmidt (1974) conducts a study on group of executives and came out with the following positive and negative outcomes of conflict.

Positive Outcomes of Conflict: These include the fact that better ideas are produced, people were forced to search for new approvals, long-standing problems surfaced were dealt with, people were forced to clarify their view, the tension stimulated interest and creativity, and that people had a chance to test their capacities.

Negative Outcomes of Conflict: Some people felt defeated, distance between people increased, a climate of suspicion and distrust developed, people and departments that needed to corporate looked after only their own narrow interests, persistence-active or passive developed were team work was needed, and that some people left because of the turmoil.

\section{STRATEGIES FOR MANAGEMENT OF ORGANISATIONAL CONFLICT}

A number of scholars have study conflict management in organizations and have proffered some workable solution to organizational conflict. Armstrong (2001) states that conflict management is the ability of an organization to identify the sources of conflict and put strategic measures in place to minimize or control conflict. In the words of Petkovic (2018), conflict management involves acquiring skills related to conflict resolution, establishing structures of conflict models, putting strategic measures as well as approaches in place. Newell (2018) asserts that conflict management focus on the principle that conflicts cannot necessarily be resolved but can be managed using appropriate actions such as accommodating, avoiding, collaborating, compromising and confrontation. Brigs (2017) adds that strategies to conflict management are a futuristic detailed approach that looks into achieving long term wins for the parties involved in conflict. Such strategies, according to him, include negotiation, collective bargaining, mediation, third party intervention, brainstorming and communication. The inevitability of conflict is caused by forces residing both inside and outside the organization. The external environments of the organization sometime change in ways that necessitate a reshuffling of priorities and resources allocation among internal subunits, and stimulate shifts in the balance of power and patterns of influence between them. A positive approach to organizational conflict is that it is absolutely necessary. Accordingly, opposition to ideas should be explicitly encouraged and both the stimulation and resolution of conflict should be encouraged. Even if this view is not hold by, management conflict in organizations is inevitable. 
Therefore, instead of avoiding conflict, organizations should endeavour to manage or reduce them to the barest minimum to the benefit of the organization. There are several managerial strategies used in managing conflict, and essentially, they are directed at the types, causes or sources, classifications and consequences of the conflict in the organization. The managerial strategies to conflict management are discussed in the following paragraphs.

Accommodation: This is tactic that can be used to neutralize the root cause of in an organization. This method is adopted to pacify all organizational members that are distressed. In addition, the strategy is appropriate when there is need for a stop-gap to be put in place or when the members have a mutually significant goal (Osad \& Osas 2013).

Controlling the Context: In order to minimize conflict that arises out of the design and layout of organizational strategies, management must formulate sound procedural strategies to institutionalize and channel conflict. Proper procedures for solving organizational conflict must be established to counter the inevitability and normality of conflict in the organization.

Conciliation: In this case, a conciliator is appointed to look into the cases and circumstances surrounding the disputes between the warring parties and negotiate with the parties in an attempt to bring about a settlement.

Joint Consultation: This could be defined as a meeting between the workers and their employers where the relationships is seen not as terms of bargaining strength but in terms of their worth and ability to contribute to the subject being discussed. Hence, discussions focus on mutual interest to both sides. According to Okpu and Jaja (2014), subjects like welfare, canteen, safety, productivity and so on are discussed. It is perhaps the joint benefit to be derived from such meeting that makes joint consultation suitable for discussing problems in industry. This is a powerful tool for resolving organizational conflicts.

Controlling the Issue in Dispute: This involves separating issues into their smallest components and dealing with them separately in attempt to make it easier to resolve major disputes. Fractioning conflict issues help to avoid stalemate by making it possible for one party to concede on one issue without feeling it has lost the contest.

Avoidance: This is another strategy that can be used in an organization in order to resolve conflict within the system. It is also known as conflict avoidance strategy. It is often said that, any organization that adopts this method will be sitting on a keg of gunpowder and postponing the evil day. It is the method used to delay conflict resolution in the organization. 
Collective Bargaining: One important attribute of collective bargaining is that it is based on the principle of voluntarism. This means that the two parties that are having conflict are expected to voluntarily iron out their differences amicably (Fajana \& Shadare, 2012).

Controlling the Relationship Directly: In adapting this strategy, management hopes to change the attitudes of the group members or individuals that are at conflict with each other. This approach is more functional in inter-group conflict. Management directly intervenes in the dispute by physically separating the unit involved on holding direct negotiations between the units or individual or formally requiring intense interaction.

Containment: In this strategy, conflicts are permitted to come up, but they are well managed by seeing to issues that required to be discussed and providing possible way out of the quagmire. The parties that are involved in conflict are given room to negotiate the outcome of the resolution (Adilo, 2019).

Altering the Individual Involved: Because altering the individual personality is much more difficult than altering his position in the organization, it may be feasible to swap the individuals in dispute.

Arbitration: The procedure of arbitration is generally time consuming, however, it has the advantage of encouraging parties at conflict. In the interim, the Head of State or the Minister of Labour can make the arbitration obligatory and binding if the possibility of a strike action is considered familial to public order or against the general interest, as in cases involving essential service (Uchendu, Anijaobi \& Odigwe, 2013).

Develop a Common Set of Goal: Much of the conflict between groups in any social organization arises because the subsystems have different goals. Most managers are rewarded through pay increases and promotions among others to the extent that they accomplish the goals and the objectives of their particular subsystem is concerned about making itself look good and is also concerned about working with other subsystems towards common goals and objectives. An approach known as the "the organizational confrontation meeting" is developed by Blackard (2001) to encourage organizational subsystems to work towards establishing and striving for common goals. 


\section{CONCLUSION}

This research work has effectively and efficiently addressed a number of issues pertaining to organizational conflict. Organization depends on the way and manner it manages the conflicts within its four walls in order to grow, survive and thrive maximally. Conflict is a state of serious disagreement and argument about something perceived to be important by at least one of the parties involved. It exists whenever an action by one party is perceived as preventing or interfering with the goals, needs or actions of another party. It is characterized by opposing interests between individuals or groups in a zero-sum situation and it involves beliefs, by each side, that the other will thwart (or has already thwarted) its interests; that is actions by one or both sides do, in fact, produce thwarting of others' goals among others. Conflicts can arise over a multiple of organizational experiences, such as incompatible goals, differences of values and philosophies or disputes over shared resources. Conflict is perception, so it begins when someone believes that another might obstruct his or her efforts. Other sources or causes of conflict are lack of resources, different expectations, competition, lack of cooperation, interdependence and communication problems. Organizational conflict has been classified differently by different scholars while the conflict has both positive and negative consequences. The last section of the study examined a number of strategies that can be used to manage organizational conflicts. Such strategies include but not limited to accommodation, controlling the context, containment, arbitration and altering the individual involved. In view of this, the researchers rightly conclude that if the organization can effectively and efficiently manage conflict within its operation, this will lead to high level of organizational performance that will result into achievement of the organizational goals and objectives. Successfully managing conflict has a dominion effect, allowing managers to create a workplace where employees can thrive.

\section{REFERENCES}

1. Adilo, J. N. (2019). Conflict management and organizational Performance: a study of selected breweries in the South East Nigeria. International Journal of Management and Entrepreneurship, 1(1), 1-22.

2. Adomie, E. E. \& Anie, S. O. (2005). Conflict management in Nigerian university libraries. Journal of Library Management, 27(8) 520-530.

3. Amason, A. C. (1996). Distinguishing the effects of functional and dysfunctional conflict on strategic decision making: Resolving a paradox for top management teams. Academy of Management Journal, 123-148. 
4. Azamosa, O. (2004) Industrial conflict in Nigerian universities: The case of the Academic Staff Union of the University Teacher's Strike of December 2002-June 2003. Dept. of Sociology, Anthropology and Applied Social Sciences, Bristol University.

5. Armstrong, M. (1990). A Hand Book of Human Resources. Paper Back Edition.

6. Armstrong, M. (2001). Strategic human resource management. Boston: Kogan Page

7. Baron, R.A. (1990) Conflict in organizations. In Murphy K.R.\& Saal, F.E. (Eds.) Psychology in Organizations: Integrating Science and Practice. Hillsdale, N.J: Erlbaum.

8. Blackard, K. (2001). Assessing workplace, conflict resolution options. Dispute Resolution Journal, 57-62

9. Bowling, N. A., \& Beehr, T. A. (2006). Workplace harassment from the victim's perspective: A theoretical model and meta-analysis. Journal of Applied Psychology, 91(5), 998-1012.

10. Brigs, S. (2017). Conflict management in the Nigerian college system.Journal of Educational and Social Research,3(8), 17-23.

11. Chinedu, U. O., Vincent, A. \& Enaini, S. O. (2018). Industrial harmony and employee performance in food and beverage firms in Anambra State of Nigeria. International Journal of Managerial Studies and Research, 6(6): 22-35.

12. Damachi, U.G. (1988). Creating industrial peace in Nigeria. In Damachi U.G and Tayo Fashoyin (Eds.) Contemporary Problems in Nigerian Industrial Relations.

13. de Wit, F. R., Jehn, K. A., \& Scheepers, D. (2013). Task conflict, information processing, and decision-making: The damaging effect of relationship conflict. Organizational Behavior and Human Decision Processes, 122(2), 177-189.

14. Fajana, S. (2000). Industrial Relations in Nigeria, 2nd Edition. Lagos: Labofin and Company.

15. Fajana, S., \& Shadare, O. (2012). Workplace relations, social dialogue and political milieu in Nigeria. International Journal of Business Administration, 3(1), 75-83.

16. Hotepo, O. M., Asokere, A. S. S., Abdul-Azeez1, I. A. \& Ajemunigbohun, S. S. A. (2010). Empirical study of the effect of conflict on organizational performance in Nigeria. Business and Economics Journal, 15, 1-9. 
17. Kazimoto, P. (2013). Analysis of conflict management and leadership for organizational change. International Journal of Research in Social Sciences, 3(1), 16-25.

18. Keenan, A., \& Newton, T. (1985). Stressful events, stressors and psychological strains in young professional engineers. Journal of Occupational Behaviour, 6(2), 151-156.

19. Liu, C., Spector, P. E., \& Shi, L. (2007). Cross-National Job Stress: A Quantitative and Qualitative Study. Journal of Organizational Behavior, 28(2), 209-239.

20. Lynem, J. N. (2003). Dangerous love: An Office romance could cost you your job. San Francisco Chronicle, Feb. 14.

21. Mullins, L. J. (2005). Management and organisational behavior. 7th Edition. Essex: Prentice Hall.

22. Newell, O.O (2018). Towards ensuring stability of academic calendar in tertiary institutions in Nigeria: A paper delivered at the national college stakeholders consultative forum held in Abuja on 31st March, 2018.

23. Obasan, K. A. (2011). Impact of conflict management on corporate productivity: An evaluative study. Australian Journal of Business and Management Research, 1(5), 44-49.

24. Obisi, C. (1996). Industrial relations. Ibadan: Freeman Productions.

25. Ojo, O., \& Abolade, D. A. (2014). Impact of conflict management on employees' performance in a public sector organisation in Nigeria. Studies in Business and Economics, 9(1), 125-133.conomics

26. Okpu, T. O., \& Jaja, S. A. (2014). Joint consultation and workers commitment in Nigeria banking industry. International Journal of Business and Management, 9(3), 53-63.

27. Omisore, B. O., \& Abiodun, A. R. (2014). Organizational conflicts: Causes, effects and remedies. International Journal of Academic Research in Economics and Management Sciences, 3(6), 1-20.

28. Osad, O. I. \& Osas, U. E. (2013). Harmonious industrial relations as a panacea for ailing enterprises in Nigeria. Journal of Asian Scientific Research, 3(3): 229-246.

29. Petkovic, E. F (2018).Staff-authority conflict and management strategies in the institutions of higher learning in Ondo and Ekiti States. Unpublished Ph.D Thesis, Department of Educational Management.

30. Pondy, L.R. (1967). Organizational conflict: Concepts and models. Administrative Science Quarterly, $12 \quad$ (2), 296-320.

31. Rahim, A.M. (2002). Toward a theory of managing organizational conflict. The International Journal of

Conflict Management, 13(3), 206-235 
32. Schmidt, W. H. (1974). Conflict: A powerful process for (good or bad) change. Management Review, 5.

33. Schramm-Nielsen, J. (2002). Conflict management in Scandinavia. Department of International Communication and Management, Copenhangan Business School, Denmark.

34. Thomas, K. W. 1976. Conflict and conflict management. Handbook in Industrial and Organizational Psychology. Chicago: Rand McNally.

35. Tochukwu, A. A. \& Ikenna, E. M. (2018). Causes and effects of conflict on workers' productivity in Enugu State College of Education (Technical) Enugu, Nigeria. Journal of Administration, 3(1), 1-13.

36. Uchendu, C., Anijaobi, F., \& Odigwe, F. (2013). Conflict management and organisational performance in secondary schools in Cross Rivers State. Nigeria Research Journal in Organisational Psychology and Educational Studies, 2(2), 67-71. 


\section{Olu Ojo}

Department of Business Administration, Faculty of Management Sciences, Osun State University, Osun State, Nigeria

oluojo@gmail.com,olu.ojo@uniosun.edu.ng

\section{Samuel Adebayo Idowu}

Department of Human Resource Management, Faculty of Social and

Management Sciences, Elizade University, Ondo State, Nigeria

idowusamueladebayo@gmail.com

\section{Haorayau Bolaji Babalola}

Department of Business Administration, Faculty of Management Sciences, Osun State University, Osun State, Nigeria

mobolajiige07@yahoo.com

\section{ORGANIZACIJSKI SUKOB: KONTEKSTALNO ISTRAŽIVANJE}

Primljen: 12. rujna 2020.

Prihvaćen: 16. studenog 2020.

https://doi.org/10.46458/27121097.2020.26.131

Pregledni rad

\section{Sažetak}

Ovaj rad istražuje koncept, uzroke, klase, posljedice i kontrolu organizacijskog sukoba. Studija je otkrila da kao i mnoga druga područja akademskog pothvata, sukob generira znatnu dvosmislenost $i$ ostavlja mnoge menadžere i znanstvenike prilično nesigurnim u pogledu njegovog značenja, izvora ili uzroka, tipologija, učinaka i lijeka. Dakle, ovo istraživanje istražuje definiciju sukoba, uzroke sukoba u organizacijskom okruženju i klasifikacije organizacijskih sukoba. Ostala raspravljana pitanja su pozitivne i negativne posljedice organizacijskih sukoba $i$ koraci koji su potrebni za upravljanje, minimiziranje i rješavanje organizacijskih sukoba. To će pomoći u širenju granice znanja u ovom području akademske discipline.

Ključne riječi: pojam sukoba, uzroci sukoba, klasifikacije sukoba, posljedice sukoba, kontrola sukoba;

JEL: D74, J52 